Portuguese Journal of Social Science Volume 16 Number 3

(C) 2017 Intellect Ltd Dossier. English language. doi: 10.1386/pjss.16.3.305_1

\title{
'Unidos por el mismo sueño en una canción': On music, gangs and flows
}

\author{
Carles Feixa, Pompeu Fabra University
}

Paula Guerra, University of Porto

\begin{abstract}
Webster's dictionary defines flow as 'a smooth uninterrupted movement' and as 'a continuous transfer of energy'. In hip hop culture, the word is used to express movements that blend in a musical and bodily sense, and by extension, a social and cultural sense. This is why the Young Latin Kings and Ñetas, two immigrant collectives in Barcelona who were considered dangerous 'Latin gangs' up until a few years ago, chose this term to name their project of conflict resolution through music. Their project was presented in 2008 , after two years of hard work in a youth centre in Nou Barris (a working-class district in Barcelona with a long tradition of hosting immigrants). This article seeks to analyse the social context and the social processes of juvenile identity (re)construction, considering the music and artistic production Unidos por el Flow of the Latin Kings and Ñetas as a major argument for the importance of music and the arts in identity (re)structuring and social inclusion of many youths.
\end{abstract}

\section{Keywords}

music 
Latin gangs

moral panic

identities

subcultures

social movements

\section{On gangs: Changes in the late modernity}

This article seeks to analyse the social context and processes of youth identity (re)construction drawing on data collected over the course of a number of fieldwork investigations conducted with gang members from 2005 to the present (Feixa et al. 2008). The text is structured in four parts. First, we present the theoretical background and the methodological approach taking into account the explanation and understanding of the identity reconstruction of the Latin Kings in contemporaneity. Second, we trace an abridged genealogy of the Latin Kings nowadays, considering their presence in Barcelona and in Cataluña as paradigmatic of the restructuring of the notion of gang in globalized times of networks and translocal flows. Third we analyse the music and artistic production Unidos por el Flow (2008) of the Latin Kings and Ñetas as a major argument for the importance of music and the arts in identity (re)structuring and social inclusion of many youths, presenting the network of actors, resources and places in this music reconciliation of gangs. Finally, we present a critical evaluation focused on the 'absent' present where the conflicts, the moral panic and the social alarm surrounding the Latin gangs are ever more present, showing the 'failures' of music as a functional 'cement' in identity reclaiming and intra- and exogang conciliator. 
This article analyses the background of a dramatic situation: the personal and social identities of young people from Latin America, arriving in Spain in the last decade. In the case of Latino gangs, those identities emerge in a border area where, on top of the hegemonic host culture and the traditional parent culture traditions, various other subcultural traditions meet (Matza 1961; Brake 1980; Venkatesh 2009). The marks of such a globalized cultural identity create a complex reasoning - one in which music is crucial to the development of social bonds, uniting individuals (Guerra 2015a, 2015d). In this sense, we can outline four basic matrixes. The first matrix begins with the North American tradition. This was tightly tied to the process of urbanization in the United States and to the process of 'magic recovery' of the original ethnic identity by second and third generations of young people whose parents or grandparents were immigrants: it was translated into the model of territorial gang, well organized and basically composed of males - the classic object of urban ethnography (Thrasher 1963; Whyte [1943] 1972). The second matrix is exemplified by the difference in scale between Latin American gang formations: pandillas and naciones. A pandilla is a social street group organized under neighbourhoods with precise geographical boundaries; naciones represent a higher level of organization, with many hundreds of members. Even though some have criminal connections, the main function of the groups is sociability: their external appearance borrows some features of hip hop culture, creating a distinctive lifestyle that solves conflict through music and dance defiance (Feixa 1998; Reguillo 2001). The third matrix is represented by the subcultural traditions that young migrants encounter when they arrive in Europe: immigrant youth are mediated by global networks to pass through local gangs to global tribes (Queirolo Palmas and Torre 2005; Esbensen and Maxson 2012). These identity negotiations take 
place in a progressively more interconnected world, in which people, ideas and traditions circulate on a scale and speed never seen (Castells 1996), thus moving away from the dichotomy of 'monolithic mainstream vs resistant subcultures' (Muggleton and Weinzierl 2003; Krüger and Trandafoiu 2013). This in turn leads us to the fourth and last matrix: the virtual and trans-local tradition represented by youth identity models that circulate through the Internet (Bennett 2001, 2004).

Against the traditional idea of cultural identities based in solid and fixed selves umbilically related to a territory and collective history, these matrixes serve to analyse the complexity and volatility of these identities. This is often brought into focus in the plasticity of human beings and the provisional nature of social roles and bonds (Featherstone 1995; Hodkinson 2002; Guerra and Bennett 2015). Analysing the way in which youths construct their traditions and identities, we are brought to a renovated model of media imperialism based on global capitalism, in which globalization and localization coexist in a complex web of network flows, showing progressive cultural homogeneity while ensuring that identity and specific values are ever more crucial in understanding popular culture (Huq 2006).

\section{On Latin gangs: Genealogy, migrations and translocalism}

Os Almighty Latin King and Queen Nation (ALQKN) were initially formed in the 1940s, in Chicago, by Latin immigrants, to defend themselves against xenophobic attacks. Their revival, in the 2000s, in Spain, marks a 'third birth' of the Nation, especially related to the migratory policies that allow family reunions (following the first phase in the United States, and the second, in Equator, in the 1990s). The members of these groups are mainly Latin Americans, in particular Ecuadorians, but with a significant 
percentage of locals, or even members coming from non-Latin countries such as Morocco, Russia or Equatorial Guinea. The majority of them are males, but there are a significant number of females (Feixa et al. 2011). These groups seem to remain stable over time, and relating to the Eurogang definition we cannot say that the involvement in illegal activities is part of their group identity (Klein et al. 2001). The fact that some of them are involved in illegal activities is not connected to their membership, but to the street policy and economy to which these adolescents and young adults are mostly subordinated.

The reason why these groups exist can first be understood through the feeling of membership that links these adolescents together in a structure of sociability, resembling a second family. The use of the word hermanito (little brother) shows the dimension of brotherhood in an organization whose main goal is not to commit crimes, but to provide some help through the act of sharing their difficult daily life in terms of protection, construction of identity and feelings of affection (Brotherton and Barrios 2003; Feixa et al. 2006; Cannarella et al. 2007). The Latin Kings and Ñetas in Barcelona represent a social reference to construct an identity and allow them to feel their own presence in a dynamic context, a homeland voluntarily understood as an imagined community - for the young stateless people or from homelands in crisis (Sancho 2009; Schoellkopf 2008). This concept draws on all the rhetoric of African American nations in the US melting pot (from the Nation of Islam to the Zulu Nation of hip hop), but fits within the post-national era in which citizenship is constructed in the interstices of the nation state, in the migration of transnational actors and in the cyber-territories (Castells 1996; Saassen 2003). 
ALQKN is a pyramidal organization ranging from the global - the nation as a rhetorical idea with transnational presence - to the local. The ideas are expressed by physical and concrete formulae that affect the daily lives of members. The Nación (Nation) is the largest structure: it gathers all the tribes across the world while also identifying the organization at the local level. The tribe is the structure within the organization corresponding to a country, although there can be more than one tribe in the same country. Within a tribe there can be kingdoms or sectors, such as the Kingdom of Madrid and the Kingdom of Catalonia. Finally, sections are the tribes' smaller-scale cells, which generally have influence over a smaller area, such as a district, a park or an underground station (Feixa et al. 2008, 2010; Feixa and Romaní 2010). We start from a specific situation within this territory, which includes the relationships and interconnections of the Catalan tribes with those in the rest of the world: their transnational connections, their different levels and their articulations based on music. The discourse of our interviewees offers a definition of who they are in terms of their basic concepts, such as the defence of the Latino culture, respect, brotherhood, etc., and offering a valuable insight into the dichotomous lives both before and after being a Latin King or Queen. More than anything, we see how it is not a univocal story: it is rooted in both individual and community experiences that perceive the group to beat times - a sacred universe, a gang, a family and a transnational organization.

The Nation as the people

Interviewer: What is a nation to you? 
King M.: A group of people who are governed by a single government, race, constitution, laws.

Interviewer: But this is a bit of a special kind of nation.

King M.: Well it is almost the same: we live here as a nation where we have a president, vice-president, secretary, treasurer, a counsellor, a war chief, teachers, our policies, rules, we have a supreme court, judges [...] Within our organization, we live as a nation within another nation, which is Spain.

According to the discourse of the Latin Kings and Queens, the Nation can be understood at three levels: at the abstract as a sacred universe that manifests its will and wisdom; at the global as a global entity, an international organization that gives unity to the different ways of being Latin Kings in different sociocultural contexts; and at the local as the people who constitute a great family, each and every one of whom are brothers and sisters, and the way in which this takes place in everyday life. If we analyse the practices, people forming the Nation may be differently placed in relation to these levels, and have different experiences in each. The relationship between members at the 'global level' is specifically unequal: while we can see its importance for the members and their sense of belonging, and granted there is some internationalization in the Nation's nature, the limits of these processes are very clear as the experience of most members of this network to its global existence. While their identities as Latino are of great importance in their definition of individuality (in contrast with the global culture that affects, albeit differently, almost everyone with transcontinental connections through the new media), this happens in much the same 
way as with many other young people who are also migrants. However, connections exist between the leaders of the organization, which can be both of mutual recognition and, at times, of conflict, linked precisely to the Latin Kings expansion process in very different contexts. Whenever a leader pays a visit, that is when ordinary members of the Nation gain a more direct experience of its transnational dimension.

\section{The Nation as a gang}

Interviewer: What is the difference between gang and nation?

King P.: A gang is where everyone does what they want, while as a nation we are all united, all striving for the same reasons: if we suffer we all suffer if we laugh, we all laugh.

King T.: The gang is almost a man, the leader. If he says, 'go and steal', they will all steal. That's why we have our own bible, our own laws. We must abide by our laws, we are a nation of organized people.

The political or cultural discourse of the Nation as a community has often been replaced and preceded by its understanding as a street group with criminal connotations (the gang) or identified with informal sociability (the peer group). The definitions that the Kings and Queens have built to explain the Nation start with denying what they are not: it is a discourse delivered from a subordinate and oppressed position, compared to that of the media, which has identified them as a gang or a criminal group. This deeply prejudiced social imaginary is the one that we found when we began our research in Barcelona in early 2005 and the one that the 
individuals of the group must face and discuss at the beginning of each interview or press conference. However, beyond this negative view of the host society, the views of the peer group are rooted at the local level in the form of collective experience. At the local level, the persistence of the Nation's ideological discourse is experienced in daily life, especially as a group of friends gathered around the chapter. Boys and girls from the same neighbourhood are recruited through shared activities, previous networks of friends, in parks and sports grounds acknowledged as Latino and eventually find membership of the Nation. One belongs to the Nation through affiliation, coexistence and by building networks of mutual help and understanding that provide them with a meaningful identity discourse in their relationships with peers.

The Nation as an organization

To introduce our culture to it, right? Because we see that the culture here is different from our culture, then we must try and say: hey! Bring the two cultures closer and embrace the culture here a little, you know? Forget a little of our ideals in our country, forget a little of our culture and adapt to what's here - you know? And adapt to the laws that are here, and the big differences between the countries, between Latin America and this country. (King F.)

In the specific case of Barcelona, the positive definition of the Nation has also gone through the legal establishment of the Cultural Organization of Latin Kings and Queens of Catalonia, which clearly differentiate it from a gang and represents the most 
symbolic and substantial change: their approach to various public institutions and services provided by Catalan society. We could say that becoming an association - not an easy negotiating process with public institutions - was an element of the Catalan Latin Kings' socialization, and as such, perhaps it had a more operational value than that of full acceptance - not in the sense of setting a politically correct screen to hide obscure activities, but rather to acknowledge the limitations underlying the translation and adaptation of the whole scope of their phenomenon into the host country's institutionally recognized models. Obviously, beyond what we have just outlined, the Latin Kings and Queens have other elements that define their Nation as an organized group - fighting against Latino social exclusion, racism and xenophobia - while aiming to contribute towards the progress of all its members so that they can have a prosperous future. In Jóvenes Latinos en Barcelona (Young People in Barcelona) (Feixa et al. 2006), we propose 'organization' as an umbrella term to encompasses various forms of youth street group belonging (from gang rule, to the Nation and the partnership). Some authors have criticized us for assuming a level of organization within the groups that did not correspond with the realities that they found in their investigations (e.g. in Madrid), where Latin gangs appear as disjointed and marginalized groups with little structure, corresponding to interpretations that are closer to social psychology and public policy - they see gangs as a way of compensating for low self-esteem (Aparicio 2008: 382). Due to their assumption that the real gang members are not those ones who participated in the organization, these authors are sceptical about the Catalan experience. Since they have not contacted organized groups or leaders, they find it inconceivable that such realities could exist beyond speech or myth: besides, the existence of a legally recognized entity does not 
necessarily replace other older and more profound organizations: the Nation as a form of (symbolic) kinship and as a field of (effective) power.

The Nation as a family

I like the way people now realize that we are not the typical people that the press have always portrayed - they realize that we are open to society and relate to everyone [...] we are working people who want to be friends with everyone [...] we are not racist like many people are here in Spain [...] we want to live a quiet life without harming anyone [...] we are with the Nation and we are with the family, which is one of the things that we want [...] many say that if we are in the Nation it is because we are in conflict with our family, our family does not understand [...] and this is a big lie, because I love my family and my family loves me. But I like the Nation and I have time for all this [...] for my family, for the Nation, for work. I even have time to get my driving license. I have time for everything, and I am not losing it because of the Nation - on the contrary, it has always given me [...] has made me find the best friends in life. (King B.)

As we have said before, the group definition attempts to present a contrary view to the hegemonic one, and therefore, must begin with the denial and then provide positive elements such as the family or brotherhood. The family, as they define it, would be associated with a network of solidarity and mutual aid, and in this sense, the Nation, understood as a family, is primarily an organization that provides support and 
security, the main functions that characterize its raison d'être. In this respect, the functions performed by the Nation among young migrant workers would be like certain lifestyles that have characterized many European working-class districts in the twentieth century, such as neighbourhood networks and different types of partnerships that were articulated as forms of organization of a certain social class.

It would be important to make one point about the relationship between the cultural imagination of the Nation and the rest of society. In line with Huq's (2006) investigation of new Asian Dance Music (NADM) and French rap music, reflecting transnational European identities, we make use of postcolonial theory in understanding that the places with greatest social and cultural dynamics, namely those in Europe, are the result of the presence of individuals from former colonies, in a process of diaspora. The presence of the Latin Kings in Catalonia in cultural terms has been one of the key aspects of its inception into mainstream acceptance: the use of musical language of hip hop and rap allows these young people to bring to the forefront of media awareness of emigration and experiences related to it. Simultaneously, this has led to a mythology of Latino culture, with many songs referring to the identity of the Kings and Queens, and telling stories that end up becoming almost a legend to the younger consumer. We know that 'Latino culture and race' are central in shaping the Nation, but when they speak of 'our culture' they refer to very heterogeneous elements from different backgrounds within the broad scope of 'Latino'.

\section{On bands: 'Unidos por el Flow'}


We are family united as one Unidos por el Flow specializing

In locating talent and growing upcoming youth

They found me, groom me up from grass to grace

No hay horizontes ni fronteras que nos separen

No hay diferencias de creencias ni de mensajes

Unidos por el mismo sueño en una canción. (Unidos por el Flow 2008) ${ }^{1}$

We've got to keep on creating life, but life from the life, 'cause otherwise it's starting over and over. It's an urban art project. The whole idea is that all young people participate, not just Latins and Ñetas, but everyone: gypsies, Nigerians [...] Other people in the neighbourhood who fancy singing with them. (Xaime López, Chispón promoter of this initiative, VV.AA. 2008).

The story of 'Unidos por el Flow' started in the CCCB Centre de Cultura Contemporània de Barcelona (Center of Contemporary Culture), in November 2005, when our study about young Latin groups was presented under the auspices of Barcelona City Hall (Feixa et al. 2006). The study revealed that although only a minority of Latin American youngsters belonged to gangs, the social imaginary had established a strong identification between Latin youngsters, gangs and hip hop culture: the rapper lookbaggy clothing - started to be mistaken as 'being in a gang'. The study also revealed 
the capacity of cultural creativity among these transnational young people who were rediscovering 'Latinity' in Europe. The study presentation allowed Ñetas and Latin Kings to become exposed and to meet each other. This gave place to what was known as the peace process. Because of the study, the Barcelona City Council and the Catalan Institute for the Human Rights fostered a process of dialogue between the two main groups, which gave rise to two new youth associations recognized by the Catalan Government: the Cultural Organization of Latin Kings and Queens of Catalonia (established in August 2006) and the Ñetas Sociocultural, Sports and Music Association (established in March 2007). Once legalized, the associations wanted to show that, beyond the violence problems that had stigmatized them before, they were able to generate social and cultural projects for the whole of the city. The most successful one was 'Unidos por el Flow'. This can be seen in the words of two key actors of each group: while King Manaba says: 'Now we're together, not as enemies, but as if we'd known each other for ever, y'know?'. Julio Bravos, a Ñeta representative, echoes the same feelings:

The important thing for me is that the message gets through. I want the message to get through for the whole world. I want everyone to see that we're together [...] All immigrants fight for the same purpose. The message is that there isn't any difference between us. 
The project was based on the principles of participative research including a group therapy technique, 'refleaction', which approaches conflict resolution through music, first coming to use in the favelas in Brazil around the intercultural hip hop. The process matured with the interaction of the educators who believed in it and who drove it at first, the young people in the Ñeta and King associations, some organizations that gave their material and moral support to it and other people who cooperated at given times, such as academics, artists and political militants. The turning point was a massive concert that took place in June 2006, where about 500 Latin Kings and Ñetas participated and ended up dancing together and rapping 'peace, peace', without any incidents. This intense communion brought out by music, well documented in many fields of inquiry (Guerra 2015c), is one that values the role of the festival as a centre for group formation and community fruition, serving as an axis of solidifying local, trans-local and virtual scenes (Fradique 2003; Simões et al. 2005). In line with the work carried out by Guerra (Guerra and Bennett 2015) on punk subcultures and diasporas, we view this music by migrant communities as a double movement of globalization and localization, combining aesthetics, music, images texts and landscapes in specificity and hybridism.

The shape the project took in 2006, having received no institutional funding, was one that also demonstrated great organizational capacity by the leaders - seeking private funding from a record label, $\mathrm{K}$ Industria Cultural, and receiving help from alternative artists such as Manu Chao and La Mala Rodriguez. The record label also provided specialized staff (audio technicians, musicians, dance and drama teachers) and took charge of the technical process of producing the record and all the products. The songs 
were created through a complex process of interaction between the young participants' imagination in the different workshops, writing the lyrics, the technical resources from the trainers and a process of production and creation of masters by the record label. While there were many youths who gave up during the process, believing it too strenuous, many continued and new and enthusiastic young people from different origins joined in.

From an internal point of view, their role as protagonists granted them intense personal valuation, but their engagement was irregular and they needed the support of the educators. The aim of creating professional spaces that allowed some of the young people to use their training for a job as singers, DJs, etc. has not happened so far, which raises a different set of questions into the conditions necessary for socioeconomic access to music in the context of migrant populations (Guerra 2015b).

This initiative shows us that music constitutes a powerful mechanism of identity reconfiguration, and especially, of showcasing one's immigrant experience to try and adapt and appropriate a new geographic context. DeNora defends that the sociology of music, for a long time, sought to explain solely the way in which music was influenced by a variety of social factors, not grasping how 'social life can be understood through music' (2003: 167). In fact, following the research we have carried out (Silva and Guerra 2015; Guerra 2015a, 2015b), music is located in the social life of individuals and that of collective entities. DeNora (2003) notes precisely a technology of the self, understanding music as individuals make use of it in defining their identities, establishes connections between music and key moments of their lives. Similarly, music allows groups to establish identities, even though it can serve to 
promote social divisions and to separate groups from each other, as it brings individuals with similar taste and cultural practices together: that is what William G. Roy and Timothy Dowd (2010) denote as a technology of the collective.

Eyerman and McCormick (2006) postulate that, besides the importance of art in forming new identities and social practices, it allows the creation of spaces of experimentation for social, political and aesthetic projects. For example, in situations of social conflict, music can provide an opportunity for reconciliation. Bergh (2007), for example, speaks of an experience undertaken in Sudan, in which rival factions made contact through music.

Similarly, we cannot forget the role of music as a form of protest (Guerra 2017). The example of the Portuguese protest song is paramount, and its correspondence to some movements of music, social and political expression in Latin America with nueva cancion and nueva trova, and in Brazil with tropicalism (Castelo Branco 2005); it has also had many correlates in South Europe, namely Spain, with voces libres and in France with nouvelle chanson (Castro 2015). This universe of music expression tends to manifest itself through different critical social configurations, discontentment, political change, resistance, proposal, action and struggle (Raposo 2010).

What we seek to demonstrate is the way in which artistic manifestations, in particular in hip hop and rap, constitute matter and object of social intervention, marking their own space in denouncing and revealing social protest against the social reality. We seek to show the voices with strong political charge, with a new cultural politics of difference (Boyd 2004) that means 
neither simply oppositional in contesting the mainstream for inclusion, nor transgressive in the avant-gardist sense of shocking conventional bourgeois audiences. Rather, they are distinct articulations of talented contributors to culture who desire to align themselves with demoralized, demobilized, depoliticized and disorganized people in order to empower and enable social action. (West 1990: 19-20).

That is, the fight for social recognition, through showcasing in music content, especially in music lyrics, xenophobia, social precarity, etc. as shown by Ventura, mentioning the Brazilian context, hip hop and rap served, besides potentiating self-esteem, as forms of approach to different cultural groups, and a vehicle 'seeking to negotiate, dialogue and confront with public authorities and institutional agents' (Ventura 2009: 607).

As we have noted, this article focuses on the main results of a large research project on a transnational migrant group of young Latin American people in Catalonia, who represent what we call Generation 1.5. These are individuals who came to Spain during the first decade of the twenty first century, while they were children or adolescents, from their countries of origin, to be reunited with their parents who had moved to Spain previously. While in 1991 only 1\% of the Spanish population was foreign, in 2002 this proportion was $8 \%$ and by 2010 it was $12.1 \%$. This migration has concentrated in Madrid and the Mediterranean coast, the most economically dynamic region, especially Catalonia (with $16 \%$ of its population being foreign in 2010) and its capital Barcelona (17.5\% in 2010). 
Although migration from Latin America to Spain began during the second half of the 1980s, it was not until after the late 1990s that it took the specific route to its current shape. While at the beginning it was a rather feminized migration, the children (mostly teenagers) started to arrive after the turn of the century. In 2012 a total of 112,331 people from north, central and south America registered in Barcelona (accounting for $6.93 \%$ of the total population), 37,954 of whom were aged $10-29$ years ( $2.34 \%$ of the population). According to the Catalan police, up to $13 \%$ of these young people belong to gangs (Idescat 2012; Visión Sociológica de España 2011).

Our analytical focus is on the works, the practices and lifestyles of music - namely in rap and hip hop - of the Latin Kings and the Netas, seeking to show how music works as a touchstone of the processes of identity (re)construction of these youths. Based on in-depth interviews of gang members, ethnographic approach and discourse analysis of songs, videos and news registers, we have sought the reconfiguration of these youths in the present (GENIND 2013-2016; Feixa et al. 2010, 2011; Romaní et al. 2012; Soler et al. 2014). The analysis of results involved elaborating narratives about group belonging (as gang, family, subculture, organization and transnational nation). ${ }^{2}$ It is at this point that we sought to analyse the individuals in their cultural belonging, seeking their individual soundtracks and the constitution of their music as a vehicle of meaning and rooting in their lives. Focusing on integrating the work of these individuals - giving them a voice in the form of a concert, and later, accompanying their DIY (do-ityourself) efforts into producing a record, ${ }^{3}$ we collaborated with educators to allow the coming together of different Latino groups and marked their symbolic discourse (Faudree 2015) in terms of originality, authorship and legitimacy: 'these are structures 
of significance that combine into singular and long-lasting works, subject to the dialectic of representation of authors, producers and consumers' (Silva and Guerra 2015: 27).

Furthermore, this initiative allowed the evaluation of the possibilities of using music, in this case of hip hop, as a form of resolving conflicts between Latin Kings and Ñetas. This is possible to note through a song title analysis (from hip hop to reggaetón, with influences from flamenco, cumbia, salsa and electronic music): the purpose of this album was to seek to reflect the lifestyles and the social practices of the youths, and to find the music that 'sing' these social factors, their life conditions, such as 'Aula Salvaje' (Savage Class), 'Pobreza' (Poverty) and 'Confinados' (Confined). On the other hand, some titles refer to the objective of conflict resolution such as 'La Paz' (Peace) and 'Unidos por el Flow' ('United for the Flow'). Following up on the perspective of Guerra (2017) and Silva and Guerra (2015), we see these songs as denouncing not only a plethora of social issues that affect their lives but also as ways to interact and act, in which the song drives to action and becomes crucial in demarking a specific place, theme and contemplation on social reality. Thus these songs assume themselves as a producing field of denouncement and protest, creating specific themes/problems, insurgent in the social reality by producing agitation and change in the reading that one makes of it, constituting at the same time the core elements of a collective identity built on self-reflexivity (Guerra 2017).

From an external point of view, the initiative had a huge media impact and helped improve the image of Latin gangs, although they still faced constant challenge through accident or tragedy. The main effect has been at the symbolic level: the young people 
empowered their own image through the culture, contributing significantly towards improving the management of their internal conflicts and tensions with the host society. This directs us to the role of music and popular culture as creator of a mediascape that seeks to mediate the cultural capital of migrant communities (Guerra and Bennett 2015). Similarly, introducing local and traditional practices of cultural production into standardized practices highlights processes of glocalization, which strengthened the cultural ties between Catalonia and the Latino communities, in line with Regev's reasoning on rock music (2013). Finally, the project had a notable transnational dimension: in another European city with Latin Kings and Ñetas - Genoa, Italy - parallel projects have taken place, and in Ecuador, where most of the young people come from, then President Rafael Correa received the Latin Kings and Ñetas and started a process of dialogue with them.

\section{On social alarm, moral panic and violence: Again and again the Latin gangs}

What were then the results? The final project, presented publicly in the social media, was a CD with 16 songs. As expected, the quality of the songs was unequal, but was marked overall by a positive note. Besides music, a multimedia book was made, which, besides the $C D$, included reports of experience, biographical notes, photos of the protagonists, academic articles, artistic drawings and a DVD documentary in which the project is explained and visualized in a promotional music video. The third result was a theatre representation: a cultural hip hop theatre, collectively created by the participants with the help of a Colombian director directly involved in the ideal of community theatre, in which the youths attempted to capture their migratory 
experience, from the initial trip to the risks of clandestine existence, finishing with photos from the statue of Columbus, establishing a conversation with the conquistador (conquer) and with the receiving society. The fourth result was centred on digital culture, with the creation of a website, a YouTube channel and conversation forums with the members of the association. The book had the support of a notable media campaign: the main news agency of Spain - EFE - publicized the event in all media outlets; one of the music programmes with the highest rating - Radiopolis - dedicated a whole emission to it and one of the supplements to the foremost Spanish newspaper - El País - published a very positive review of the experience (Yúdice 2002).

On 2 February 2013, a 16-year-old teenager was killed as he was leaving a park in the Madrid suburb of Puente Vallecas. According to the subsequent police investigation, the murder was an act of revenge between the two major Latino gangs in Spain: the Latin Kings and Ñetas (Feixa and Canelles 2007). The case takes us back to another assassination, this time in Barcelona on 28 October 2003, when the Colombian adolescent Ronny Tapias was killed by a group of young people as he was going home from school (EFE 2005). According to the police investigation, the murder was an act of revenge by Ñetas gang members, who allegedly confused the youth with a member of the Latin Kings with whom they had had a fight in a club a few days earlier. After a month, nine Dominicans and Ecuadorians were arrested. Three juveniles were tried and convicted (including the perpetrator of the crime) (Feixa et al. 2011).

Following this event and others that took place later in Madrid and Barcelona, the alarms raised by the Spanish Ministry of Home Affairs and the media resulted in an increasingly stigmatized image of Latin American youth and generated a wave of 
'moral panic' that has not eased since. Consequently, the thousands of young people who arrived in Barcelona after 2000 (due to various family reunification processes) found themselves exiled from their homes and social networks at one of the most critical moments of their lives (the difficult transition to adulthood), while having to deal with frightened adults (fathers and mothers, teachers, neighbours, police officers, etc.) because of legal and institutional boundaries. Their new forms of sociability, transgressing geographical boundaries to rebuild global identities, were thus wrongly associated with the image of the 'traditional gang', being closer to a neighbourhoodproximity network or a surrogate family (as we shall discuss below). We are thus close to the context described by Stanley Cohen 40 years ago in Clacton, in the United Kingdom, regarding the Mods and the Rockers (1972).

In recent years, coinciding with the dramatic effects of the financial crisis that has been felt particularly badly among young people and migrants, the so-called Latino gangs have once again become protagonists on the crime news, the 'New Waves' of moral panic. However, the scale of police intervention has increased, as has the notoriety of the names of the groups involved, and the processes of social rejection that target them. The Spanish media has carried extensive and lurid reports and images of a dozen massive police raids on major gangs, carried out by different police forces and leading to the arrest of hundreds of young people, with the reports using such emotive terms as 'decommissioning', 'beheading', 'eradicating' and 'dismantling' these gangs (although they are quick to reform and the reports almost never recount just how many of those arrested are eventually tried and convicted). ${ }^{4}$ The question remaing is: had it been worth being 'united by the flow'? 


\section{On the relevance of the music in the (re)construction of identity}

At this time one must strike a record: what was the impact of the initiative? From an internal point of view, the youths felt themselves intervening, active in the project, but with irregular spurts of activity, requiring more or less regular support from the intervenients; one of the objectives was to develop professional careers that would allow professional engagement with the world of music, which up until now has not occurred. From an external point of view, the initiative had a great repercussion, improving the image of the Latin gangs in Barcelona, despite the occurrence of tragic events bringing back classic and stigmatizing images from the media. From the point of view of the cultural product, the lack of professionalization was shown to be less than important for the quality of the product: despite the disc not having been a great success, it was far from a commercial failure. The initial intention to compete in Eurovision and to apply for the MTV awards for young bands did not happen. From the organizational point of view, the UPF Association was established, with a young Latin boy presiding it, stemming from neither of the groups. However, the action of the organization became lethargic with the departure of Chispón, the animator who had been from the start engaged with the project, and due to it changing headquarters to another place in the centre of Barcelona. Perhaps the most important change occurred on a symbolic level: the youths became empowered to improve their image through culture, contributing for better ways to resolve internal conflicts, and overall in terms of the tensions with the society that welcomes them. Finally, the project had a European and International dimension: in Genova, another city with both Latin Kings and Ñetas, parallel initiatives took place; in Equator, the home of many of these youths, there was a political facilitation of security measures against gangs, allowing 
the formation of Latin Kings associations. Namely, in Madrid, there was a recognition that police policies undertaken until then had not borne any good fruits, and that cultural interventions were more profitable in terms of safety as a way of promoting social inclusion and preventing violence.

What has failed? As discussed, it is our firm belief that we should attempt to relate the results of these investigations with the other vertices of the triangle built around youth (research, policy and work). When these exchanges are numerous, fertile or positive, the result is the strengthening of areas for youth participation. By adopting a method of investigation-action, we have sought to avoid placing young people as the subject, but rather as the object, risking their symbolic invisibility and disappearance from centre stage (Tommasi 2013). The danger of such situations, when youth research decreases or is fed with media stereotypes, lies in how youth policies suffer cutbacks or are subordinated to security policies, and youth work survives on the basis of voluntary work and austerity (Oliart and Feixa 2012). Moreover, the same media stereotypes that elicit moral panic and construct an image of deviance also tend to increase the complexity of contemporary urban life, associating a notion of delinquency with the symbolic identity (the hip hop clothing) (Tickner 2008): as is classic of the mods and rockers in the United Kingdom during the 1960s or of the punks in Mediterranean countries (Cohen 1972; Pais et al. 2004).

Equating the evolution of association between research, action and work, the cultural evolution and belonging of individuals soon stands out as a major asset in terms of migrant community integration into a receptive community. In our perspective, the importance placed on the youth migrant perspectives, assuming their own cultural 
notions and views, and promoting unity in the communities through projects such as 'Unidos por el Flow' - in line with the work defended by Silva and Guerra (2015) and Regev (2013) - constitutes, even after the social changes brought by the crisis, a strong axis through which social cohesion can be achieved. Taking into consideration the complex socio-political conjunctures that we have been faced in this research, it has become clear that the challenges now facing young migrants constitute a step towards cultural globalization, overcoming the immaterial fears of modernity and promoting intense unity by local institutions and youth associations, law enforcement policies and transnational perspectives.

\section{Acknowledgements}

This article is supported in two research projects: TRANSGANG: Transnational Gangs as Agents of Mediation: Experiences of conflict resolution in youth street organizations in Southern Europe, North Africa and the Americas. European Union: HORIZON-2020, European Research Council - Advanced Grant [H2020-ERC-AdG-742705]; and KISMIF: Keep it Simple, Make it Fast! Prolegomenos and Punk Scenes: A Road to Portuguese Contemporaneity (1977-2012) (FCT - Fundação da Ciência e da Tecnologia, Portugal, 2012-15 (PTDC/CS-SOC/118830/2010).

\section{References}

Aparicio, R. (2008), 'Psicología evolutiva, psicología social y bandas latinas en Madrid' ('Evolutionary psychology, social psychology and latin bands in Madrid'), in J. García Roca and J. Lacomba (eds), La inmigración en la sociedad española: Una 
radiografia multidisciplinar (Immigration in Spanish Society: A Multidisciplinary Radiography), Barcelona: Bellaterra, pp. 379-402.

Bennett, A. (2001), Cultures of Popular Music, Buckingham: Open University Press.

Bennett, Andy (2004), 'Consolidating the music scenes perspective', Poetics, 32:3-4, pp. 223-34.

Bergh, A. (2007), 'I'd like to teach the world to sing: Music and conflict transformation', Musicae Scientiae, 11:2, Special Issue, pp. 141-57.

Boyd, Todd (2004), 'Check Yo Self Before You Wreck Yo Self: The death of politics in rap music and popular culture', in Mark Anthony Neal and Murray Forman (eds), That's the Joint!: The Hip-Hop Studies Reader, New York and London: Routledge, pp. 325-40.

Brake, M. (1980), The Sociology of Youth Culture and Youth Subcultures: Sex and Drugs and Rock ' $n$ ' Roll, London: Routledge. 
Brotherton, David and Barrios, Luis (2003), The Almighty Latin King and Queen Nation.

Street Politics and the Transformation of a New York City Gang, New York:

Columbia University Press.

Cannarella, Massimo, Lagomarsino, Francesca and Queirolo Palmas, Luca (eds) (2007), Hermanitos. Vita e politica della strada tra i giovani latinos in Italia, Verona: Ombre Corte.

Castells, M. (1996), The Rise of the Network Society, Cambridge: Blackwell.

Castelo Branco, Edwar de Alencar (2005), Edwar de Alencar. Todos os dias de paupéria: Torquato Neto e a invenção da Tropicália (Edwar de Alencar. Every day of paupéria: Torquato Neto and the Invention of Tropicália), São Paulo: Annablume.

Castro, Hugo (2015), ‘Discos na Revolução: A produção fonográfica da canção de protesto em Portugal na senda da Revolução do 25 de Abril de 1974' ('Albuns in Revolution: The phonographic production of protest song in Portugal in the wake of the 25th of April Revolution'), TRANS-Revista Transcultural de Música/Transcultural Music Review, 19, pp.1-28. 
Cohen, S. (1972), Folk Devils and Moral Panics: The Creation of the Mods and Rockers, Cambridge: Basil Blackwell.

DeNora, T. (2003), 'Music sociology: getting the music into the action', British Journal of Music Education, 20:2, pp. 165-77.

EFE (2005), 'Empieza el juicio contra seis pandilleros por el asesinato del colombiano Ronny Tapias' ('Trial of six gang members for the murder of Colombian Ronny Tapias begins'), www.libertaddigital.com/sociedad/empieza-el-juicio-contraseis-pandilleros-por-el-asesinato-del-colombiano-ronny-tapias-1276248136. Accessed 15 July 2015.

Esbensen, F.-A. and Maxson, C. (eds) (2012), Youth Gangs in International Perspective: Results from the Eurogang Program of Research, New York, NY: Springer.

Eyerman, R. and McCormick, L. (eds) (2006), Myth, Meaning, and Performance: Toward a New Cultural Sociology of the Arts, Boulder, CO: Paradigm.

Faudree, P. (2015), 'Singing for the dead, on and off line: Diversity, migration, and scale in Mexican Muertos music', Language and Communication, 44, pp. 31-43. 
Featherstone, M. (1995), Undoing Culture: Globalization, Postmodernism and Identity, London: Sage.

Feixa, C. (1998), De Jóvenes, Bandas y Tribus (Of Youths, Bands and Tribes), Barcelona: Ariel.

Feixa, C. and Canelles, N. (2007), 'De bandas latinas a asociaciones juveniles: La experiencia de Barcelona' ('From latin bands to youth associations: The Barcelona experience'), Educação, 30:1, pp 11-28.

Feixa, C. and Romaní, O. (2010), 'Catalan Kings versus Global Kings. Riflessioni sulla glocalizzazione degli imaginari culturali' ('Catalan Kings versus Global Kings: Reflections on glocalization of the cultural imaginary'), in L. Queirolo Palmas (ed.), Atlantico Latino: Gang giovanili e culture transnazionali (Latin Atlantic: Juvenile Gangs and Transnational Cultures), Rome: Carocci, pp. 73-84.

Feixa, C., Porzio, L. and Recio, C. (eds) (2006), Jóvenes 'Latinos' en Barcelona: Espacio Público y Cultura Urbana ('Latin' Youth in Barcelona: Public Space and Urban Culture), Barcelona: Anthropos.

Feixa, C., Scandroglio, B., López, J. and Ferrándiz, F. (2011), ‘¿Organización cultural o asociación ilícita? Latin kings entre Madrid y Barcelona' ('Cultural organization 
or illicit association? Latin Kings between Madrid and Barcelona'), Papers: Revista de Sociología, 96:1, pp. 145-63.

Feixa, C., Canelles, N., Porzio, L., Recio, C. and Giliberti, L. (2008), 'Latin Kings in Barcelona', in F. van Gemert, D. Peterson and I.-L. Lien (eds), Street Gangs: Migration and Ethnicity, Cullompton: Willan, pp. 63-78.

Feixa, C., Romaní, O., Hakim, N., Latorre, A., Porzio, L. and Rodríguez, A. (2010), 'Spain: Irregular lives in the southern rim of Europe', in K. Fangen, K. Fossan and F.-A. Mohn (eds), Inclusion and Exclusion of Young Adult Migrants in Europe: Barriers and Bridges, London: Ashgate, pp. 17-50.

Fradique, T. (2003), Fixar o movimento. Representações da música rap em Portugal (Fix the Mouvement. Representations of Rap Music in Portugal), Lisboa: Publicações D. Quixote.

GENIND (2013-2016), ‘La generación indignada. Espacio, poder y cultura en los movimientos juveniles de 2011: Una perspectiva transnacional' ('The indignant generation: Space, power and culture in youth movements 2011: A transnational perspective'), Ministerio de Economía y Competividad, VI Programa Nacional de Investigación Científica, Desarrollo e Innovación 
Tecnológica (CSO2012-34415), genindyoungpower.blogspot.com.es. Accessed 15 July 2015.

Guerra, P. (2015a), 'Keep it rocking: The social space of Portuguese alternative rock (1980-2010)', Journal of Sociology, 52:4, pp. 615-30.

(2015b), 'Sonhos pop: Criação, aura e carisma na música moderna portuguesa' ('Pop dreams: Creation, aura and carisma in modern Portuguese music'), ECompós, 18:1, pp. 1-22.

(2015c), 'Flying away: Electronic dance music, dance culture, psytrance and new sounds in Portugal', in E. Simão, A. Malheiro da Silva and S. Tenreiro de Magalhães (eds), Exploring Psychedelic Trance and Electronic Dance Music in Modern Culture, Hershey, PA: Information Science Reference, pp. 307-36. (ed.) (2015d), More Than Loud: Os Mundos Dentro de Cada Som (More Than Loud: The Worlds in Each Sound), Porto: Afrontamento.

(2017), 'A canção ainda é uma arma: ensaio sobre as identidades na sociedade portuguesa em tempos de crise' ('The song is still a weapon: essay about identities in Portuguese society during times of crisis'), in Francisco de Assis de Sousa Nascimento, Jaison Castro Silva, Ronyere Ferreira da Silva (eds), História 
e Arte: Teatro, cinema, literatura (History and Art: Theater, Cinema, Literature).

Teresina: EDUFPI, pp. 149-172.

Guerra, P. and Bennett, A. (2015), 'Never mind the pistols? The legacy and authenticity of the sex pistols in Portugal', Popular Music and Society, 38:4, pp. 500-21.

Hodkinson, P. (2002), Goth: Identity, Style and Subculture, Oxford: Berg.

Huq, R. (2006), Beyond Subculture: Pop, Youth and Identity in a Postcolonial World, London: Routledge.

Idescat (2012), Evolució de la Població Total i Estrangera: 2000-2010 (Evolution of Total and Foreign Population: 2000-2010), Barcelona. Idescat, www.idescat.cat/poblacioestrangera/?b=0andnac=aandres=a. Accessed $01 \mathrm{July}$ 2015.

Klein, M. W., Kerner, H.-J., Maxson, C. L. and Weitekamp, E. (eds) (2001), The Eurogang Paradox: Street Gangs and Youth Groups in the US and Europe, London: Kluwer.

Krüger, S. and Trandafoiu, R. (eds) (2013), The Globalization of Music in Transit: Music Migration and Tourism, London: Routledge. 
Matza, D. (1961), 'Subterranean traditions of youth', in H. Silverstein (ed.), The Sociology of Youth: Evolution and Revolution, New York, NY: Macmillan, pp. $252-71$.

Muggleton, D. and Weinzierl, R. (eds) (2003), The Post-Subcultures Reader, Oxford: Berg.

Oliart, P. and Feixa, C. (2012), 'Youth studies in Latin America: On social actors, youth policies and new citizenships', Young, 20:4, pp. 329-44.

Pais, J. M., Brito, J. P. and Carvalho, M. V. (2004), Sonoridades Luso-Afro-Brasileiras (Luso-Afro-Brazilian Sounds), Lisbon: Imprensa de Ciências Sociais.

Queirolo Palmas, L. and Torre, A. T. (eds) (2005), Il Fantasma delle Bande: Giovani dall'America Latina a Genova (The Ghost of Gangs: Youth from Latin America to Genoa), Genoa: Fratelli Frilli.

Raposo, O. (2010), “'Tu és rapper, representa Arrentela, és red eyes gang”: sociabilidades e estilos de vida de jovens do subúrbio de Lisboa' (“'You’re a rapper, represent Arrentela, you're from the Red Eyes Gang": Sociabilities and 
life styles of young people from the suburbs of Lisbon'), Sociologia-Problemas e Práticas, 64, pp. 127-47.

Regev, M. (2013), Pop-Rock Music: Aesthetic Cosmopolitanism in Late Modernity, Cambridge: Polity.

Reguillo, R. (2001), Emergencia de Culturas Juveniles (The Emergence of Youth Cultures), Buenos Aires: Norma.

Romaní, O., Feixa, C. and Latorre, A. (2012), 'Being heard or being seen', in K. Fangen, T. Johansson and N. Hammaren (eds), Young Migrants: Exclusion and Belonging in Europe, London: Palgrave-Macmillan, pp. 146-73.

Roy, W. G. and Dowd, Timothy. J. (2010), 'What is sociological about music?', Annual Review of Sociology, 36, pp. 183-203.

Saassen, S. (2003), Los espectros de la globalización (The Spectres of Globalization), México: FCE. 
Sancho, X. (2009), ‘El “flow” hace la unión', El País, EP3, 27 February.

https://elpais.com/diario/2009/02/27/tentaciones/1235762575_850215.html. Accessed 0107 2015,

Schoellkopf J.-L. (2008), 'Altres xarxes socials: els Latin kings', in VV.AA.. (eds), Imatges metropolitanes de la nova Barcelona, Barcelona: Macba-El Periódico, pp. 16-17.

Silva, A. S. and Guerra, P. (2015), As Palavras do Punk: Uma Viagem Fora dos Trilhos pelo Portugal Contemporâneo (The Words of Punk: A Trip Off the Rails by Contemporary Portugal), Lisbon: Alêtheia.

Simões, J. A.; Nunes, P. and Campos, R. (2005), 'Entre subculturas e neotribos: propostas de análise dos circuitos culturais juvenis. O caso da música rap e do hip-hop em Portugal' ('Between subcultures and neotribos: Proposals for analysis of youth cultural circuits. The case of rap music and hip-hop in Portugal'), Fórum Sociológico, 13/14, pp. 171-89.

Soler, P., Planas, A. and Feixa, C. (2014), 'Youth and youth policies in Spain in times of austerity: Between juggling and the trapeze', International Journal of Adolescence and Youth, 18:3, www.tandfonline.com/doi/full/10.1080/02673843.2013.823552. Accessed 31 July 2017. 
Thrasher, F. M. (1963), The Gang: A Study of 1313 Gangs in Chicago, Chicago, IL: University of Chicago Press.

Tickner, A. B. (2008), 'Aquí en el Ghetto: Hip-hop in Colombia, Cuba and Mexico', Latin American Politics and Society, 50:3, pp. 121-46.

Tommasi, L. (2013), ‘Culturas de periferia: Entre o mercado, os dispositivos de gestão e o agir político'('Periphery cultures: Between the market, management devices and political action'), Política \& Sociedade, 12:23, pp. 11-34.

Unidos por el Flow (United for the Flow) (2008), Barcelona: Latin Kings, Ñetas y Jóvenes de Barcelona, KL Industria (CD).

Venkatesh, S. (2009), Gangs: Leader for a Day, London: Penguin.

Ventura, Tereza (2009), 'Hip-hop e graffiti: uma abordagem comparativa entre o Rio de Janeiro e São Paulo' ('Hip-hop and graffiti: A comparative approach between Rio de Janeiro and São Paulo'), Análise Social, XLIV:192, pp. 605-34. 
Visión Sociológica de España (2011), 'Extranjeros en Países Europeos' ('Foreigners in European Countries'), visionsociologica.es/Contexto\%20internacional/extranjeros_paises_europeos.p hp. Accessed 15 July 2015.

VV.AA. (2008), Latin kings, ñetas y otros jóvenes de Barcelona... Unidos por el Flow, Barcelona: K. Industria Cultural.

West, Cornel (1990), 'The new politics of difference', in Russell Ferguson, Martha Gever, Trinh T. Minh-ha and Cornel West (eds), Out There: Marginalization and Contemporary Cultures, New York and Cambridge: The New Museum of Contemporary Art and MIT Press, pp. 19-38.

Whyte, W. F. ([1943] 1972), Street Corner Society, Chicago, IL: University of Chicago Press.

Yúdice, G. (2002), El recurso de la cultura. Usos de la cultura en la era global (The Resource of Culture. Uses of Culture in the Global Era), Barcelona: Gedisa.

\section{Contributor details}


Carles Feixa is professor of social anthropology at the Department of Communication of Pompeu Fabra University (Catalonia, Spain). He has investigated youth cultures and has conducted fieldwork in Spain and Latin America. He is the author of several books such as De jovenes, bandas y tribus (Barcelona, 1998; 5th edition 2012), Jovens na America Latina (São Paulo, 2004) and Global Youth? (Carles Feixa and P. Nilan, Routledge, London and New York, 2006). He has been advisor for youth policies of the United Nations and vice president of the International Sociological Association Research Committee 'Sociology of Youth'.

Paula Guerra is professor of sociology at University of Porto (Portugal), a senior researcher in the Institute of Sociology (IS-UP), invited researcher at the Centre for Geography Studies and Territory Planning in the Faculty of Arts and Humanities, University of Porto (FLUP) and adjunct professor at Griffith Centre for Cultural Research at Griffith University in Queensland, Australia. She is the author of The Unstable Lightness of Rock: Genesis, Dynamics and Consolidation of Alternative Rock in Portugal (1980-2010). Guerra is currently the principal researcher for 'Keep it simple, make it fast! Prolegomena and punk scenes, a way for Portuguese contemporaneity (1977-2012)', an international interdisciplinary project about the Portuguese punk scene funded by the Portuguese Foundation for Science and Technology, and a researcher in other projects.

Contact:

Carles Feixa, Universitat Pompeu Fabra, Roc Boronat, 138 08018 Barcelona, Spain. 
Paula Guerra, Faculdade de Letras da Universidade do Porto, Via Panorâmica, s/n, 4150-564 Porto, Portugal.

E-mail: carles.feixa@upf.edu

E-mail: paula.kismif@gmail.com

Notes

* United by the same dream in a song (trad).

${ }^{1}$ No horizons and boundaries that separate us/ No differences of belief or messaging/ United by the same dream through a song.

${ }^{2}$ In an assembly of the ALQKN Spain celebrated in 2006 in Barcelona, we collected sociodemographic data from 118 gang members who responded to the survey (out of the approximately 300 group members): $68.6 \%$ (81) were men and $31.4 \%$ (37) were women. The average age was 18.5 years, with the men being slightly older at 18.81 than the women at 17.83 . About $70 \%$ were Ecuadorian, with most of the remaining $30 \%$ being Spanish (working-class background and migrant within Spain, with more women than men), followed by other Latin American nationalities. In general, they tend to have left school early, so have low levels of education and perform unqualified, low-paid and precarious jobs often without a contract.

${ }^{3}$ The final product was a CD containing sixteen songs of different genres and styles, which included contributions from various members. Apart from the music, a multimedia book was produced that, alongside the $C D$, included a chronicle of the 
entire experience, biographical stories and pictures of the participants, academic texts, drawings and a documentary DVD.

${ }^{4}$ On 26 January 2010, Operation Shelved was executed against the Bloods in Pamplona, which involved more than 200 police officers and led to the arrest of 39 people aged 14-25 years. On 15 February 2010, Operation Crown was carried out against the Latin Kings in Madrid, leading to the arrest of 53. In November 2011, another operation was carried out against the Latin Kings in Pamplona, leading to the arrest of 28 people aged 15-22 years. Before July 2011, 80 people were arrested over the course of five operations carried out against the Latin Kings and Ñetas in Murcia. On 28 November 2012, 21 were arrested during Operation Bracelet against Trinitarios in Lleida. On 18 February 2013 a 'macro-operation' against the Black Panthers in Barcelona and Zaragoza, which involved 150 police officers, led to the arrest of 25 . On 26 February 2013, an operation in Madrid against Dominican Don't Play (DDP) and Bloods resulted in 33 arrests (fifteen of which were minors). This is without mentioning the many smaller operations that were carried out against Mara Salvatrucha, Mara 18, the Crips, the Forty-Two and others. 